\title{
A Quantitative Analysis of Socioeconomic Impacts of Sea Level Rise on the Anzali International Coastal Wetland
}

\author{
Roya Mousazadeh ${ }^{1}$, Hamidreza Ghaffarzadeh ${ }^{2 *}$, Jafar Nouri', \\ Alireza Gharagozlou ${ }^{3}$, Mehdi Farahpour ${ }^{4}$ \\ 'Department of Environmental Management, Graduate School of the Environment and Energy, \\ Science and Research Branch, Islamic Azad University, Tehran, Iran \\ ${ }^{2}$ Department of Environmental Economics, Graduate School of the Environment and Energy, \\ Science and Research Branch, Islamic Azad University, Tehran, Iran \\ ${ }^{3}$ Geomatics College of National Cartographic Center of Iran (NCC), Tehran, Iran \\ ${ }^{4}$ Faculty Member of Research Institute of Forests and Rangelands, \\ KM Expert MENARID GEF and Iranian Joint Projects, Tehran, Iran
}

Received: 18 April 2016

Accepted: 5 July 2016

\begin{abstract}
This is a two-phase study to investigate the socioeconomic impacts of the Caspian Sea Level Rise (CSLR) on Anzali International Wetland at the southern fringe of the Caspian Sea. In the first phase, a Landsat satellite image (2013) and digital elevation model (DEM) of the wetland were used to determine the areas vulnerable to the CSLR-induced flooding under four water level rise scenarios of $0.2 \mathrm{~m}, 0.6 \mathrm{~m}$, $1 \mathrm{~m}$, and $1.4 \mathrm{~m}$. Then in the second phase, the possible effects of the CSLR on some market values of Anzali Wetland and the livelihood of the wetland-dependent communities were assessed based on the loss of agricultural and fishing products (as two main sources of livelihood for local people), as well as the loss of different land uses surrounding the wetland. According to the results, under the most optimistic CSLR scenario of $0.2 \mathrm{~m}$, the wetland area will be expanded from 19,095 to 24,942 ha, while an expansion of 19,353 ha (from the current area of 19,095 ha to 38,448 ha) is expected under the most pessimistic CSLR scenario of $1.4 \mathrm{~m}$. This will affect a minimum number of eight villages, including 4,518 inhabitants (under the CSLR scenario of $0.2 \mathrm{~m}$ ) and a maximum number of 41 villages including 22,493 inhabitants (under the 1.4 CSLR scenario). These people will have to displace and move from their homes, which leads to several social ills. Depending on the severity of water level rise under various scenarios, 545, 646, 670, and 699 ha of the total area (790 ha) of fish ponds will be destructed, and total numbers of 70, 76, 83, and 93 units out of the 172 active industrial units are predicted to be inundated. In sum, the total loss values (damage to agriculture and fish farming) under the CSLR scenarios of $0.2,0.6,1$, and $1.4 \mathrm{~m}$ were estimated to be
\end{abstract}

*e-mail: hamidreza.ghaffarzadeh@gmail.com 
\$63 million (USD), \$117 million, \$151 million, and \$184 million, respectively. Our research findings can help policy makers develop proper adaptation measures to prohibit or reduce the possible socio-economic damage caused by the CSLR in the future.

Keywords: Anzali Coastal Wetland, Caspian Sea, water-level rise, digital elevation model, quantitative assessment

\section{Introduction}

The Caspian Sea is enclosed on all four sides without any major outlet, which makes the lake a fragile ecosystem. It is bound to the south by Iran over an area of around $813 \mathrm{~km}^{2}(11.6 \%$ of the entire area of the sea). Since a large volume of the seawater is supplied from the Volga River, we can conclude that the fluctuation of the seawater is a function of fluctuations in the river [1]. This is somehow confirmed by historical events. According to records, the highest and lowest discharge rates occurred respectively in 1994 and 1975, when the Caspian Sea experienced two main water-rise and water-fall periods. Statistical analysis also revealed that the discharge rate of the Volga correlates with fluctuations in Caspian Sea levels, and the greatest correlation of 0.72 was found in the period between 1938 and 2010 [2]. The interaction between the Caspian and neighboring terrestrial ecosystems has led to the creation of a few important marginal water bodies with unique features, one of the most important of which is Anzali Wetland [3]. In 1975, Anzali was registered during the Ramsar Convention as a wetland of international importance [4]. The wetland has an average height of $26 \mathrm{~m}$ below sea level and changes in area depending on fluctuations in Caspian water levels, as well as total precipitation rate in the basin of the wetland [5]. In mid-1980, coastal areas of Anzali Wetland were flooded under the onslaught of massive waves that led to the loss of 430 ha of residential areas on the western fringe [6].

Generally, changes in the sea level would be due to natural or global anthropogenic effects on climate. This, for the inland Caspian Sea, would be natural as a result of changes in the balance of inputs as river flow and outputs as evaporation rate. The geological instabilities play little role in this regard. According to the historical records, natural fluctuations in Caspian levels are mainly influenced by the two factors of climate change and variation in discharge of the rivers flowing into the sea [7]. As predicted by the Intergovernmental Panel on Climate Change (IPCC), the sea level is expected to rise $18-59 \mathrm{~cm}$ by the end of the $21^{\text {st }}$ century [8], and a study by Filizadeh et al. [9] predicts that by 2017 the Caspian will rise about $1.2 \mathrm{~m}$ as a result of melting polar ice caps.

Wetlands are one of the ecosystems that are directly affected by the rising water level. They occupy $6 \%$ of the world's land surface area and include approximately $12 \%$ of the global carbon pool [10]. Some researchers have shown the importance of preserving wetlands through valuating the ecosystem services they offer. As such, de Groot et al. [11] estimated the average service value of the coastal wetlands in 2007 as 193,845 Int.\$/ha/year [11]. The total value of the 63 million ha of wetlands in the world is estimated to be approximately $\$ 3.4$ billion per year. This value is higher in Asia ( $\$ 1.8$ billion per year), where there are more valuable wetlands. It will increase even up to $\$ 70$ billion per year if the extent of all wetlands $\left(12.8\right.$ million $\left.\mathrm{km}^{2}\right)$ cited in the Ramsar Convention sites also is included [12]. Wetlands serve as protectors of coastal regions from storms, carbon sequestration, and nutrient transformation. They are also main providers of organic matter and nursery grounds that support commercial fisheries. Despite the enormous economic benefits of wetlands (approx. $\$ 10,000 /$ ha), about $25-50 \%$ of the world's coastal tidal wetlands have disappeared due to their extensive conversion into agricultural lands and fish ponds. It is predicted that conversion of wetlands to open water will be accelerated in the future so that around $20-45 \%$ of salt marshes are expected to be lost during the current century. Loss of wetlands in the world is mainly due to simultaneous effects of either sea-level rise or human activities, rather than just the effect of sea-level rise alone. A rich environment of wetlands with diverse ecosystem services provides a good place for the livelihood and living of human communities. Population growth in coastal areas and accelerated sealevel rise have intensified the tight interactions between society and coastal wetlands [13]. In research by Blankespoor et al. [14], the impact of $1 \mathrm{~m}$ rise in sea level on coastal wetlands of a total number of 86 developing countries and territories was investigated. According to their findings, flooding risk engendered $68 \%$ of the coastal wetlands. China and Vietnam in East Asia and the Pacific, Libya and Egypt in the Middle East and North Africa, and Romania and Ukraine in Europe will undergo the greatest losses. They estimated the economic burden of losses as more than $\$ 703$ million per year (in 2000 USD; Blankespoor et al. 2014) [14]. Cui et al. [15] used the source-pathway-receptorconsequence (SPRC) model to analyze potential impacts of sea-level rise on coastal wetlands in the Yangtze estuary. By quantification of effective indicators, they provided a vulnerability index and spatially zoned flood-prone areas in the estuary based on the vulnerability degrees. To ensure the preservation of the vulnerable wetlands in the estuary from the risk of water intrusion, they proposed some mitigation measures including the management of sedimentation, rehabilitation, and re-creation of wetland habitats, reduction of land subsidence, and control of reclamation [15]. In a purely economic point of view, Haer et al. [16] warned about the possible risks of future sealevel rise for coastal populations and GDP in the United States. They used GIS to calculate the impacts of sea-level 
rise on land inundation, endangered populations, and GDP loss. They predicted that 26,000 to $76,000 \mathrm{~km}^{2}$ of land will be inundated, which will endanger more than 1.8 to 7.4 million people and lower U.S. GDP by $\$ 70-289$ billion annually [16].

In 2010 Natesan and Parthasarathy [17] investigated the impact of SLR on the coastal zone of the Kanyakumari District in India. They detected inundation zones along the coastal area using integrated DEM and GIS overlay techniques. They analyzed inundation vulnerability based on the anticipated SLR scenarios of $0.5 \mathrm{~m}$ and 1 $\mathrm{m}$. According to their results, sea level rise would lead to permanent inundation of about $13 \mathrm{~km}^{2}$ of Kanyakumari, resulting in land loss, an altered coastal zone, and disturbed coastal ecosystems. Carretero et al. [18] attributed the saltwater intrusion length into aquifers to intensified water use so that the higher annual consumption rate decreased the volume of freshwater. As reported by Zaid et al. [19], SLR in Mediterranean coastal provinces will make 4 million people homeless and cause the loss of 0.5 million jobs [19]. One of the most negative impacts of rising sea level is increased salinity of soil and water in coastal areas, which brings negative unintended consequences such as intrusion of salinity and loss of farmlands, biodiversity, and fresh water, as well as damage to aquaculture activities. Salinity of water and soil resources induced by seal level rise can strongly decrease agricultural productivity. In 2005 Sarwar recommended altering traditional monoculture to poly-culture in order to combat declined land productivity caused by SLR in coastal areas of Bangladesh [20]. In a study by the World Bank in 2000 [21], it was revealed that increased salinity caused by a 0.3 meter SLR can reduce land productivity for paddy cultivation as 0.5 million metric tons. Sabaei et al. [22] recommended reconsidering a legal buffer of the Caspian Sea at the southern fringe due to changes in the coastline caused by SLR. Voutsina et al. [23] suggested reclaiming lands salted by water inundation using indigenous plant species such as halophytic nurse crops. Saleem khan et al. [24] used shuttle radar topographic mission (SRTM) DEM to identify areas at risk of inundation. They recommended ecosystem-based adaptation and community-based adaptation to mitigate the impacts of SLR [24].

Water level rise in the Caspian Sea can directly affect natural ecosystems such as the Anzali Wetland. Loss of indigenous living species and replacement by invasive species are among the most important negative effects of sea-level rise that can alter the function of ecosystems [25].

According to a study by the Bandar-e Anzali Water and Wastewater Company, almost $80 \%$ of the municipal and industrial effluent from coastal cities is discharged directly into the Caspian Sea without any pretreatment. SLR puts wetlands and other coastal ecosystems at risk of pollution from industrial and municipal wastewater. If not controlled, these contaminants will be broadcast elsewhere by SLR [26].

Considering the several economic consequences of CSLR on local communities, it is essential to valuate sector-specific quantitative damage caused by flooding in order to realize the breadth and scope of SLR on agriculture and fishing activities, as well as local livelihoods. Accordingly, the present study was carried out to quantify possible consequences of CSLR on land use types, industrial centers, and villages, as well as damage to agriculture and fishing activities in the artificial fishfarming ponds.

\section{Materials and Methods}

\section{Study Area}

Our study area is Anzali Wetland, which lies between northern latitudes of $37^{\circ} 15^{\prime}-37^{\circ} 35^{\prime}$ and eastern longitudes of $49^{\circ} 10^{\prime}-49^{\circ} 40^{\prime}$, near which are the cities of Rasht and Some'esara. Annual rainfall and fluctuations in the water level of the Caspian are two main causes for variations in the area of the wetland. Since the first water rise in 1977 , the area of the wetland has been increasing. The water level of Anzali Wetland is $26 \mathrm{~m}$ lower than the open sea level [5]. Large freshwater lagoons with reed beds and meadows provide appropriate spawning, nursery, and breeding places for fish and a variety of waterfowl [27]. The current area of Anzali is approximately 19,095 ha, which includes the water body and reed beds. Of this, we investigated 65,553 ha. Siahkeshim Protected Area (3935 ha) and the three wildlife refuges of Selkeh

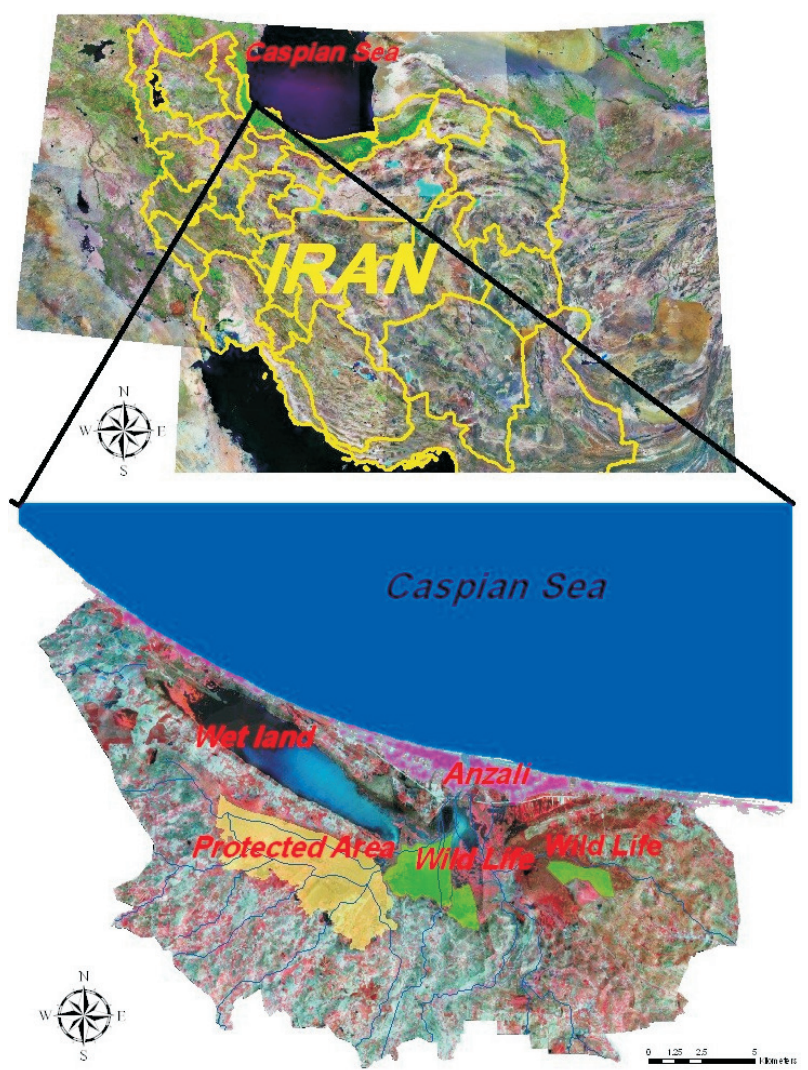

Fig. 1. Situation of the study area in Iran and the Caspian Sea. 
(360 ha), Sorkhnkol (1,209 ha), and Choukam (443 ha) add to the ecological value of the wetland. Fig. 1 illustrates situation of the study area in Iran and the Caspian Sea.

\section{Materials}

In this study, the land use map of the study area was prepared using a Landsat TM8 image from 2013. Furthermore, the digital topographic map of the wetland at a scale of 1:25,000 (including 10-contour lines) was prepared by the National Cartographic Center of Iran to geo-reference the images and to prepared a digital elevation model (DEM), and slope map. This map was generated based on aerial photos from 1993. It also was used to determine ground-truth points for supervised classification and accuracy assessment. Data processing at various steps was done using ERDAS Imagine (version 9.2) and Arc Info (version 9.3) software.

\section{Methods}

As an initial step, different water-level rise scenarios were defined. For this purpose, it was assumed that the water level will rise $0.2,0.6,1$, and $1.4 \mathrm{~m}$ in the future. In the next step, the inundation risk zones were identified using DEM in the event of any of the water rise scenarios. Subsequently, a land use map of the study area was prepared on which the fish ponds, farmlands, population centers, and industrial sites were clarified. Overlaying the inundation risk zones and land use map of the study area, economic losses on the various productive sectors were calculated on market value. Fig. 3 demonstrates the flow diagram of the research procedure, and a detailed description on research methodology follows.

\section{Land Use Mapping}

According to JICA [27], there are generally three main zones in the biosphere reserves: core, buffer, and transition. Based on this, the Anzali Wetland could be divided into three zones of wetland, buffer, and transition. The boundary of the study area was delineated based on the wetland's transition zone [27].

As mentioned earlier, the land use map of the study area was prepared from a Landsat TM8 image. For this, the stack layers of TM sensor (bands 2-7) were used and corrected geometrically according to the topographic map at the scale of 1:25,000. The data set was configured in the projected coordinate system of WGS84 UTM Zones $39 \mathrm{~N}$.

The image was classified using the supervised signature extraction method on the basis of maximum likelihood algorithm. This classification algorithm leads to viable results for most prevalent types of habitats [28-29]. Backed by sufficient field knowledge, groundtruth points were selected using the on-screen polygonal training data selection method [30]. Based on spectral similarity with the training points, various pixels of the image were classified into different land use classes so that homogeneous polygons with similar spectral reflectance were labeled the same. This process was used to control the accuracy of the classified map [29]. After verifying the ground truth, the land use map of 2013 was prepared using visual interpretation. Fig. 2 illustrates the land use map of the study area for 2013.

Overall accuracy of the prepared land use map was estimated by error matrix at $89.1 \%$, which falls within the acceptable range.

\section{Creating DEM and Slope Map}

For creating the DEM, we extracted main streams, elevation points, and contour lines from a 1:25,000-scale topographic map of the study area. The prepared DEM had a pixel size of $10 \mathrm{~m}$. The interpolation errors at border sites were decreased by a $300-\mathrm{m}$ buffered topographical map. The virtual sinks were estimated at 513 filled using neighborhood analyses with a $3 * 3$ filter. The slope map (in percent) was also prepared from the DEM.

\section{Prediction of Inundation Zones under CSLR Scenarios}

In this step, the map of inundation zones already derived from DEM was overlaid with the maps of land use, villages, industrial centers, and fish ponds to recognize different sectors affect by the CSLR.

\section{Quantifying the Impacts of CSLR on Market Values}

In order to valuate consequences of water-level rise, we supposed difference water level rise scenarios. Accordingly, the extent of the inundation risk zone was determined in the event of each of the water level rise scenarios. It should be mentioned that at each inundation risk zone, the submerged land uses, villages, industrial centers, farmlands, and fish ponds that are likely to be at risk of flooding were identified. Then, based on the market price for the services and real estate, economic losses caused by flooding were calculated in units of per hectare

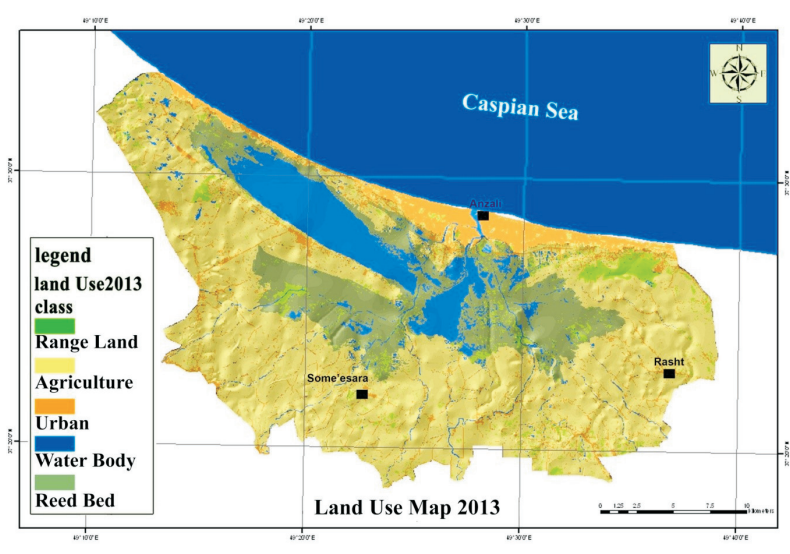

Fig. 2. Land use map of the study area in 2013. 


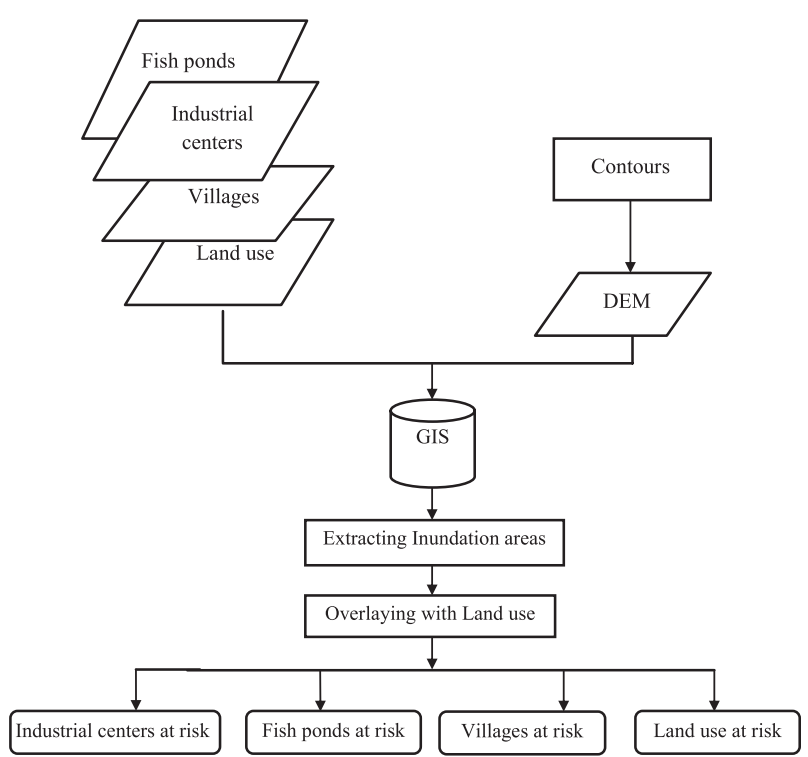

Fig. 3. Research procedure.

per year and sum per year.

Since the majority of local people rely on fish ponds and farmland for their livelihood, we investigated the impact of water rise on the fishing and farming professions.

Accordingly, we estimated direct economic losses of four sea-level rise scenarios $(0.2,0.6,1$, and $1.4 \mathrm{~m})$ to local agriculture and fish farming. In general, this study presents a framework for identifying, mapping, and valuating the negative consequences of water rise on the Anzali Wetland of northern Iran.

\section{Results and Discussion}

The livelihood of about $63 \%$ of the residents living in the surrounding wetland is from agriculture and the income source of the remaining $24 \%$ is from fishing. Therefore, the most important economic consequence of rising sea level will be inflicted on agriculture and fisheries. Given that the bulk of agricultural production in the region is devoted to rice, damage to agricultural products was estimated based on the inundation of $72 \%$ of the agricultural land area under rice cultivation [31]. Table 1 presents changes in the area of different land uses under various CSLR scenarios.

As Table 1 suggests, farmlands occupy an area of 37,585 ha in the study area. It is expected that under various water level rise scenarios of $0.2 \mathrm{~m}, 0.6 \mathrm{~m}, 1 \mathrm{~m}$, and $1.4 \mathrm{~m}$, the area of agricultural lands is reduced by 32,408 ha, 27,636 ha, 24,584 ha, and 21,653 ha, respectively. Rangelands cover an area of 2,979 ha in Anzali Wetland and surroundings. Raising the water level to $0.2 \mathrm{~m}, 0.6 \mathrm{~m}, 1 \mathrm{~m}$, and $1.4 \mathrm{~m}$ will lead to loss of $1,160 \mathrm{ha}$, 1,009 ha, 954 ha, 848 ha of the rangelands, respectively. Built-up areas that extend over an area of 7,020 ha are expected to decline to 6,311 ha, 5,363 ha, 4,954 ha, and 4,204 ha in the event of water level rise scenarios of $0.2 \mathrm{~m}, 0.6 \mathrm{~m}, 1 \mathrm{~m}$, and $1.4 \mathrm{~m}$, respectively. Reed beds, which cover an area of 10,712 ha, are expected to decline as 97 ha, 50 ha, 30 ha, and 17 ha under various water level rise scenarios. The water body that lays in an area of 7,257 ha is predicted to increase by $25,578 \mathrm{ha}$, 31,496 ha, 35,033 ha, 38,854 ha under the influence of different water level rise scenarios. Figs $4 a-b$ demonstrate the changing area of farmlands and the water body in the event of various CSLRs. Generally, out of the total study area, $57 \%$ is occupied by farmlands, $16 \%$ by wetland cover (reed beds), $11 \%$ by urban areas, and $5 \%$ by rangelands.

According to Fig. $4 \mathrm{~b}$, the area of farmlands decreased from $-13.77 \%$ under the $0.2-\mathrm{m}$ CSLR scenario to $-42.39 \%$ under the 1.4-m CSLR scenario.

Depending on the severity of water level rise, more and more industries will be affected in the study area so that in the event of $0.2 \mathrm{~m}, 0.6 \mathrm{~m}, 1 \mathrm{~m}$, and $1.4 \mathrm{~m}$ scenarios, a total number of $70,76,83$, and 93 industries (out of the total 172 active industries in the study area) will be damaged, respectively. They include $40.7 \%, 44.2 \%, 48.3 \%$, and $54.1 \%$ of total industries, respectively.

According to Table 2 , there are 128 villages in

Table 1. Land use category of the study area in the base year and the estimated area of land use changes under different CSLR scenarios.

\begin{tabular}{|c|c|c|c|c|c|c|c|c|c|c|}
\hline & \multicolumn{2}{|c|}{ Agriculture } & \multicolumn{2}{|c|}{ Rangeland } & \multicolumn{2}{|c|}{$\begin{array}{c}\text { Urban and built-up } \\
\text { areas }\end{array}$} & \multicolumn{2}{|c|}{$\begin{array}{c}\text { Reed bed } \\
\text { cover }\end{array}$} & \multicolumn{2}{c|}{ Water body } \\
\cline { 2 - 12 } SLR Scenarios & $\begin{array}{c}\text { Area of } \\
\text { land use } \\
\text { (ha) }\end{array}$ & $\begin{array}{c}\text { Reduction } \\
\text { of land } \\
\text { use area } \\
\text { (ha) }\end{array}$ & $\begin{array}{c}\text { Area } \\
\text { of land } \\
\text { use } \\
\text { (ha) }\end{array}$ & $\begin{array}{c}\text { Reduction } \\
\text { of land } \\
\text { use area } \\
\text { (ha) }\end{array}$ & $\begin{array}{c}\text { Area } \\
\text { of land } \\
\text { use } \\
\text { (ha) }\end{array}$ & $\begin{array}{c}\text { Reduction } \\
\text { of land } \\
\text { use area } \\
\text { (ha) }\end{array}$ & $\begin{array}{c}\text { Area } \\
\text { of land } \\
\text { use } \\
\text { (ha) }\end{array}$ & $\begin{array}{c}\text { Reduction } \\
\text { of land } \\
\text { use area } \\
\text { (ha) }\end{array}$ & $\begin{array}{c}\text { Area } \\
\text { of land } \\
\text { use } \\
\text { (ha) }\end{array}$ & $\begin{array}{c}\text { Increased } \\
\text { area of } \\
\text { water } \\
\text { body } \\
\text { (ha) }\end{array}$ \\
\hline 2013 & 37,585 & 0 & 2,979 & 0 & 7,020 & $\cdot$ & 10,712 & $\cdot$ & 7,257 & 0 \\
\hline By 0.2 m SLR & 32,408 & $-5,177$ & 1,160 & $-1,819$ & 6,311 & -709 & 97 & $-10,615$ & 25,578 & 18,321 \\
\hline By 0.6 m SLR & 27,636 &,- 9949 & 1,009 & $-1,970$ & 5,363 & $-1,657$ & 50 & $-10,662$ & 31,496 & 24,239 \\
\hline By 1 m SLR & 24,584 & $-13,001$ & 954 & $-2,025$ & 4,954 & $-2,066$ & 30 & $-10,682$ & 35,033 & 27,776 \\
\hline By 1.4 m SLR & 21,653 & -1 & 848 & $-2,131$ & 4,204 & $-2,816$ & 17 & $-10,695$ & 38,854 & 31,597 \\
\hline
\end{tabular}




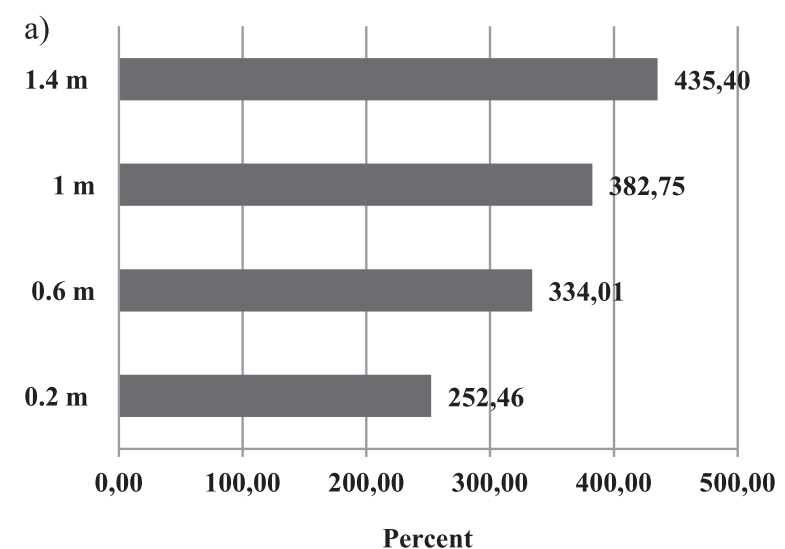

b)

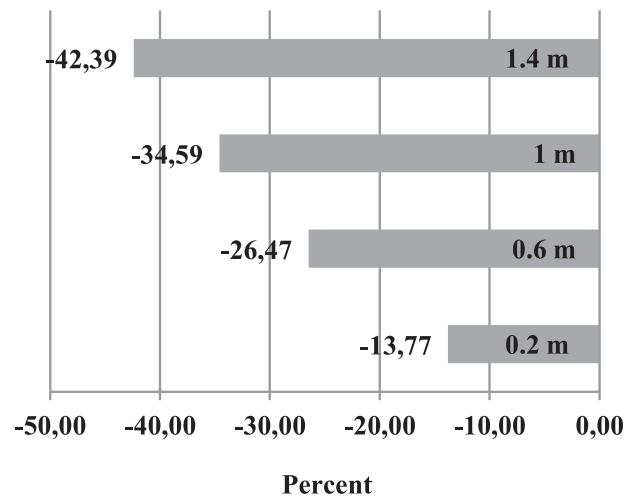

Fig. 4. Changing trends (in \%) in the area of the water body a) and farmlands b) under different CSLR scenarios.

the study area, including a total population of 79,371 inhabitants. Under the influence of the $0.2-\mathrm{m}$ water level rise scenario, the population of eight villages (including 5,418 people) is expected to suffer from damage and loss. The high intensity of water rise will engage more people from other villages, so that 15 villages $(9,218$ people) will be affected by a $0.6-\mathrm{m}$ water level rise, and 28 villages $(15,118$ people) will be influenced by a $1 \mathrm{~m}$ water level rise. The greatest impact on 41 villages, including a total population of 22,493 people, will occur in the event of $1.4 \mathrm{~m}$ water-level rise scenario.

As Table 3 suggests, there are 91 fish ponds in Anzali Wetland and its surroundings, which occupy an area of 790 ha. The area of fish farms affected by CSLR rise varies under different sea-level rise scenarios, so that a $0.2 \mathrm{~m}$ rise
Table 3. Number and area of fish ponds affected by water level rise under various scenarios.

\begin{tabular}{|c|c|c|}
\hline $\begin{array}{c}\text { Water level rise } \\
\text { scenarios }\end{array}$ & $\begin{array}{c}\text { Area of affected } \\
\text { fish ponds (ha) }\end{array}$ & $\begin{array}{c}\text { Number of } \\
\text { affected fish } \\
\text { ponds }\end{array}$ \\
\hline Year 2013 & 790 & 91 \\
\hline $0.2 \mathrm{~m}$ & 545 & 55 \\
\hline $0.6 \mathrm{~m}$ & 646 & 68 \\
\hline $1 \mathrm{~m}$ & 670 & 68 \\
\hline $1.4 \mathrm{~m}$ & 699 & 72 \\
\hline
\end{tabular}

in water level will involve a small patch of the fish farms in an area of $545 \mathrm{ha}$, while a $1.4 \mathrm{~m}$ rise in the sea level will expand flooded areas over an area of 699 ha. As the water level rises, many more fish farms will be inundated, so that a $0.2-\mathrm{m}$ rise in sea level will lead to a loss of 55 fish farms, while a 1.4-m rise will destroy a greater number (72) of the fish farms. Table 4 shows the market value of agricultural (rice) and fishery products in 2013. Market value of agricultural products in the study area was estimated as 10.4 million Iranian Rial (IRR; equivalent to $\$ 416$ million US in 2013). The value per hectare for the products is 384 million IRR $(\$ 15,360)$. Furthermore, the market value of fish farming was estimated at 221200 million IRR ( $\$ 8.8$ million). The value per hectare for fish production is about 280 million IRR $(\$ 11,200)$. The total value of agricultural products and fish production were estimated at 10612624 million IRR (\$425 million). (Our calculations were based on the 2013 IRR-to-USD exchange rate as announced by the Central Bank of the Islamic Republic of Iran: 1 USD equal to 25,000 IRR [32].)

According to Table 5, economic losses for the agricultural sector in the event of different CSLR scenarios will be 1431168 million IRR ( $\$ 57$ million), 2750592 million IRR (\$110 million), 3594624 million IRR (\$144 million), and 4404864 million IRR (\$176 million), respectively. The economic values of the lost fish production in fish ponds caused by SLRs of 0.2, 0.6, 1 , and $1.4 \mathrm{~m}$ were estimated to be about 152600 million IRR (\$6.1 million), 180880 million IRR (\$7 million), 187600 million IRR (\$7.5 million), and 195720 million IRR (\$7.8 million), respectively. The total loss values

Table 2. Number and percent of villages and population affected by water level rise under various scenarios.

\begin{tabular}{|c|c|c|c|c|}
\hline \multirow{2}{*}{} & \multicolumn{2}{|c|}{ Number of villages } & \multicolumn{2}{c|}{ Population } \\
\cline { 2 - 5 } & \multicolumn{2}{|c|}{128} & \multicolumn{2}{c|}{791} \\
\hline $\begin{array}{c}\text { Water level rise } \\
\text { scenarios }\end{array}$ & $\begin{array}{c}\text { Number of affected } \\
\text { villages }\end{array}$ & $\begin{array}{c}\text { Percentage of affected } \\
\text { villages }\end{array}$ & $\begin{array}{c}\text { Population } \\
\text { population }\end{array}$ \\
\hline $0.2 \mathrm{~m}$ & 8 & 6.3 & 4,518 & 5.7 \\
\hline $0.6 \mathrm{~m}$ & 15 & 11.7 & 9,218 & 11.6 \\
\hline $1 \mathrm{~m}$ & 28 & 21.9 & 15,118 & 19.0 \\
\hline $1.4 \mathrm{~m}$ & 41 & 32.0 & 22,493 & 28.3 \\
\hline
\end{tabular}


Table 4. Market value of agricultural and fishery products.

\begin{tabular}{|c|c|c|c|c|}
\hline Type of market value & $\begin{array}{c}\text { Total value in } \\
2013 \\
\text { Million IRR }\end{array}$ & $\begin{array}{c}\text { Total value in } \\
2013 \\
\text { Million USD }\end{array}$ & $\begin{array}{c}\text { Value per ha } \\
\text { Million IRR }\end{array}$ & $\begin{array}{c}\text { Value per ha } \\
\text { USD }\end{array}$ \\
\hline $\begin{array}{c}\text { Agricultural products } \\
\text { (paddy*) }\end{array}$ & 10391424 & 416 & 384 & 15,360 \\
\hline $\begin{array}{c}\text { Fish production in } \\
\text { ponds** }\end{array}$ & 221200 & 8.8 & 280 & 11,200 \\
\hline Sum & 10612624 & 425 & - & - \\
\hline
\end{tabular}

*Average rice yield in $2013=4,800 \mathrm{~kg} / \mathrm{ha}$ and price per $\mathrm{kg}$ of paddy in $2013=80,000$ IRR [33-34]

**Fish yield per unit of pond area $=3,500 \mathrm{~kg}$ of live fish with an average price of 80,000 IRR per $\mathrm{kg}$ [34-35]

Table 5. Total lost values in agriculture and fish farming due to SLR under different scenarios.

\begin{tabular}{|c|c|c|c|c|c|c|c|c|}
\hline $\begin{array}{r}\text { Seal level rise } \\
\text { scenario }\end{array}$ & $\begin{array}{c}\text { Loss value } \\
\text { in million } \\
\text { IRR under } \\
0.2 \mathrm{~m} \text { sea } \\
\text { level rise }\end{array}$ & $\begin{array}{c}\text { Loss value } \\
\text { in million } \\
\text { USD under } \\
\text { of } \\
\text { loss value }\end{array}$ & $\begin{array}{c}\text { Loss value in sea } \\
\text { million IRR } \\
\text { level rise }\end{array}$ & $\begin{array}{c}\text { Loss value } \\
\text { sea level rise } \\
\text { in million } \\
\text { USD under } \\
0.6 \mathrm{~m} \text { sea } \\
\text { level rise }\end{array}$ & $\begin{array}{c}\text { Loss value } \\
\text { in million } \\
\text { IRR under } \\
1 \mathrm{~m} \text { sea } \\
\text { level rise }\end{array}$ & $\begin{array}{c}\text { Loss value } \\
\text { in million } \\
\text { USD under } \\
1 \mathrm{~m} \text { sea } \\
\text { level rise }\end{array}$ & $\begin{array}{c}\text { Loss value } \\
\text { in million } \\
\text { IRR under } \\
1.4 \mathrm{~m} \text { sea } \\
\text { level rise }\end{array}$ & $\begin{array}{c}\text { Loss value } \\
\text { in million } \\
\text { USD } \\
\text { under } \\
1.4 \mathrm{~m} \text { sea } \\
\text { level rise }\end{array}$ \\
\hline $\begin{array}{c}\text { Agricultural } \\
\text { products (rice) }\end{array}$ & 1431168 & 57 & 2750592 & 110 & 3594624 & 144 & 4404864 & 176.2 \\
\hline Fish production & 152600 & 6.1 & 180880 & 7 & 187600 & 7.5 & 195720 & 7.8 \\
\hline Total loss value & 1583768 & 63 & 2931472 & 117 & 3782224 & 151 & 4600584 & 184 \\
\hline
\end{tabular}

(damage to agriculture and fish farming) under sea level scenarios of $0.2,0.6,1$, and $1.4 \mathrm{~m}$ were estimated at 1583768 million IRR (\$63 million), 2931472 million IRR (\$117 million), 3782224 million IRR (\$151 million), and 4600584 million IRR (\$184 million), respectively.

The SLR will impose significant effects on the lowlying coastal zones. The coastal wetlands in northern Iran, including Anzali Wetland (because of their low altitude below sea level), are particularly vulnerable to SLR. The CSLR can lead to economic losses on the livelihoods of the local communities (in agriculture and fishing sectors). Submerging a large area of land by sea-level rise leads to extensive land use changes and the relocation of residents surrounding the wetlands, which brings serious social problems.

In this regard, conservation of vulnerable areas, highlypopulated centers, commercial centers, and the fragile ecosystem from the consequences of SLR would be of utmost importance. Based on the foregoing, a number of short- and long-term mitigation and adaptation measures are recommended for Anzali Wetland.

Simultaneous use of hard and soft structures: hard structures can act as a barrier between the Caspian Sea and the properties at risk. Hard engineering would be the first possible response of many Caspian communities to future SLR. New seawalls, bulkheads, revetments, breakwaters, and levees are just a few examples of hard structures that seem to be suitable for the conservation of non-armored coastal areas against inundation. In addition to the used of hard engineering structures, soft structures are also proposed as an auxiliary operation. Soft structures refer to beach nourishment, artificial wetlands, and littoral drift replenishment. They can prevent inundation of the exposed structures.

Engineering measures are recommended as a long-term strategy to upgrade existing structures or to construct new flood-resistant structures in areas prone to inundation. For Anzali Wetland, beach nourishment seems to be a suitable long-term engineering measure. Another management approaches to prevent or reduce the impacts of SLR are: fortifying urban infrastructure and existing residential structures and buildings against SLR, controlling invasive species, reinforcing rehabilitation of wetland ecosystems (conservation of the Anzali Protected area together with its rich biodiversity), land use modification by changing the farmlands to fish farming ponds or by planting floodresistant of halophyte crops (it is recommended to change paddy fields surrounding the Anzali Wetland to fish lagoons), legislating stricter regulations that ban new development projects at inundation zones, and insuring private and public properties against the risk of flooding.

Other damage caused by rising sea levels is the intrusion of saline water into the coastal wetland. This could lead to the displacement or extinction of some indigenous plant and animal species as well as change the function of ecosystems. In order to avoid further loss in the agricultural sector, it is proposed to change the cropping pattern (e.g., breeding of varieties resistant to salt in fish farms, or cultivating halophyte species in farmlands instead of salt-sensitive crops in order to avoid further loss 
in the agricultural sector).

Intensive land use change is another adverse effect of SLR that should be managed in the form of and integrated coastal zone management (ICZM) approach. Application of GIS software in the form of a decision support system can be quite useful for developing and planning the wetland in the future. Suitable zoning of the wetland area and the control of population density and building construction are among the management measures highly recommended in flood-prone areas.

The findings of this study can help policy makers develop proper adaptation measures and suitable policies to prohibit or reduce possible socio-economic and cultural damage caused by SLR in the study area in the future.

\section{Conclusions}

Depending on the severity of water level rise, more and more sectors will be affected in the Anzali Wetlands, leading to loss of agricultural crops. The total loss values (damage to agriculture and fish farming) under sea-level scenarios of $0.2,0.6,1$, and $1.4 \mathrm{~m}$ were approximated to be $\$ 63$ million, $\$ 117$ million, $\$ 151$ million, and $\$ 184$ million, respectively. The $0.2-\mathrm{m}$ water level rise scenario is expected to damage eight villages with 5,418 inhabitants. In the event of a $1.4 \mathrm{~m}$-water-level rise scenario, a large number of villages (41 villages), including a total population of 22,493 people, will be damaged. In conclusion, SLR will cause much socioeconomic damage. Accordingly, attempts should be made to control this event and the arising effects to the extent possible.

\section{References}

1. MORADMAND,P., FARAHANI,F., KHORISHIDI,M. Study on fluctuations of the Caspian Sea level in recent years. Iran Meteorol. Org., 2005 [In Persian].

2. GHANGHERMEH A. Report on the fluctuations of the Caspian Sea in the water year of 2009-2010. National Centre for Studies and Research of the Caspian Sea, Water Research Institute, Ministry of Energy, Tehran, Iran, 2011.

3. MALEK J., SHATAEI JOUYBARI S.H. An investigation on changes in the natural landscape and land uses on the southern shores of the Caspian Sea using aerial photos and GIS. J. Geograph. Res. 37 (51), 95-105 [In Persian], http:// fa.journals.sid.ir/ViewPaper.aspx?id=37186, 2005.

4. www.ramsar.org/country-profiles.x

5. ASHOORI A., ABDOOS A. Important wetland habitats for the waterbirds of Gilan. Katibeh Gyll Publication, Tehran, Iran. 2013 [In Persian].

6. CEP and UNDP. Anzali Lagoon Adaptive Management Pilot Initiative Project, Caspian Environment Programme, 2007.

7. Transboundary Diagnostic Analysis For the Caspian Sea Volume Two, the Caspian Environment Programme Baku, Azerbaijan, 2002.

8. IPCC. Climate change 2007: the physical science basis. Summary for policy makers, Intergovernmental Panel on Climate Change, 2007.

9. FILIZADEH Y., ZOLFINEJAD K., RAJABI ISLAMI H. Planning for the Impacts of the Caspian Sea Level Rise and Climate Change in the North of Iran, Global Warming, Green Energy and Technology, Dincer et al. (eds.), Springer Publisher, 683, 2010.

10. ERWIN K.L. Wetlands and global climate change: The role of wetland restoration in a changing world. Wetl. Ecol. Manag. 17, 71, 2009.

11. DE GROOT R., BRANDER L., VANDERPLOEG S., COSTANZA R., BERNARD F., BRAAT L., CROSSMAN N., HEIN L., HUSSAIN S. Global estimates of the value of ecosystems and their services in monetary units. Ecosyst. Serv. 1, 50, 2012.

12. BRANDER A.L., SCHUYT K. Benefits transfer: The economic value of world's wetlands. The economics of ecosystems and biodiversity, 1, 2012.

13. KIRWAN M.L., MEGONIGAL J.P. Tidal wetland stability in the face of human impacts and sea-level rise. Nature, $\mathbf{5 0 4}$ (7478), 53, 2013. Available at: http://www.ncbi.nlm.nih.gov/ pubmed/24305148.

14. BLANKESPOOR B., DASGUPTA S., LAPLANTE B. SeaLevel Rise and Coastal Wetlands. Ambio. J Hum Environ, 43, 996, 2014.

15. CUI L., GEA Z., YUANA L., ZHANGA L. Vulnerability assessment of the coastal wetlands in the Yangtze Estuary, China to sea-level rise. Estuar. Coast. Shelf Sci. 156, 42, 2015.

16. HAER T., KALNAY E., KEARNEY M., MOLL H. Relative sea-level rise and the conterminous United States: Consequences of potential land inundation in terms of population at risk and GDP loss. Global Environ. Chang. 23, 1627, 2013.

17. NATESAN U., PARTHASARATHY A. The potential impacts of sea level rise along the coastal zone of Kanyakumari District in Tamilnadu, India. J. Coast. Conserv. 14, 207, 2010.

18. CARRETERO S., RAPAGLIA J.P., BOKUNIEWICZ H.J., KRUSE E. Impact of sea-level rise on saltwater intrusion length into the coastal aquifer, Partido de La Costa, Argentina. Cont. Shelf Res. 61-62, 62, 2013.

19. ZAID S.M., MAMOUN M.M., AL-MOBARK N.M. Vulnerability Assessment of the Impact of Sea Level Rise and Land Subsidence on North Nile Delta Region. World Appl. Sci. J., 32, 325, 2014.

20. MD. GOLAM MAHBUB SARWAR. Master thesis with title of "Impacts of Sea Level Rise on the Coastal Zone of Bangladesh". Lund University International Masters Programme in Environmental Science, 2005.

21. WORLD BANK. Bangladesh: Climate Change and Sustainable Development. Report No. 21104 BD, Dhaka. www.ramsar.org/country-profiles.x, 2000.

22. SABAEI S.M., DANEHKAR A., DARVISHSEFAT A.A., GHANGHORMEH A., ABDI O. Review on the legal limits of the Caspian Sea considering the changes in sea water level: a case study of Guilan Province. Biannual J. Land Use Plan. 3, 136, 2011. http://fa.journals.sid.ir/ViewPaper. aspx?id $=195783$.

23. VOUTSINA N., SELISKAR D.M., GALLAGHER J.L. The facilitative role of kosteletzkya pentacarpos in transitioning coastal agricultural land to wetland during sea level rise. Estuar. Coast. 38, 35, 2014.

24. SALEEM KHAN A., RAMACHANDRAN A., USHA N., PUNITHA S., SELVAM V. Predicted impact of the sealevel rise at Vellar-Coleroon estuarine region of Tamil Nadu coast in India: Mainstreaming adaptation as a coastal zone management option. Ocean Coast. Manag. 69, 327, 2012.

25. FILIZADEH Y. Workshop on Anzali Lagoon Adaptive Management Pilot Initiative Project. Department of 
Environment of Guilan, Guilan Province, Iran, 2007.

26. YAZDANPANAH N., FARSHCHI P., FILIZADEH U. Forecast of climate change and CSLR impacts on biological activities of Anzali Wetland. The First Conference on Climate change and Towards Sustainable Future, 2014. http://www. civilica.com/Paper-CCHFGG01-CCHFGG01_044

27. JICA AND DOE. Anzali Wetland ecological management project in the Islamic Republic of Iran (Zoning Plan in the Anzali Wetland), Japan International Cooperation Agency and Department of Environment the Islamic Republic of Iran, 7, 2012.

28. DONOGHUE D.N.M., MIRONNET N. Development of an integrated geographical information system prototype for coastal habitat monitoring. Computat. Geosci. 28, 129, 2002.

29. ARDIL E.R., WOLFF M. Land use and land cover change affecting habitat distribution in the Segara Anakan lagoon,
Java, Indonesia. Reg. Environ. Change. 9, 235, 2009.

30. WENG Q. Land use change analysis in the Zhujiang Delta of China using satellite remote sensing, GIS and stochastic modeling. J. Environ. Manag. 64, 273, 2002.

31. CENESTA. Anzali Wetland Ecological Management Project. Socio-Economic Survey [part-2], Centre for Sustainable Development, Tehran, Iran, 2012.

32. CENTRAL BANK OF IRAN, www.cbi.ir.

33. DAJAC. Department of Agricultural Jihad of Anzali City, 2013. Available at: www.jkgc.ir.

34. GILAN CENSUS. 2013 http://www.amar.org.ir/english.

35. GDF, Gilan Department of Fisheries, 2013. Available at: www.shilat-gilan.ir 
